СЛ. Р. Шостакович-Корецька, К. Ю. Литвин, І. О. Губар, О. О. Волікова, 3. О. Чикаренко, О. А. Кушнєрова, О. В. Шевельова Дз “Дніпропетровська медична академія мОз України”

\title{
АНАЛІЗ ЗМІН СИРОВАТКОВОГО БЕТА-2-МІКРОГЛОБУЛІНУ ТА ПОКАЗНИКІВ ГЕМАТОЛОГІЧНОГО ПРОФІЛЮ У ПАЦІЄНТІВ ІЗ ВІЛ-АСОЦІЙОВАНИМИ НЕВРОЛОГІЧНИМИ ЗАХВОРЮВАННЯМИ
}

\begin{abstract}
Резюме. Пацієнти 4 клінічної стадії ВІЛ-інсекції із неврологічними захворюваннями мають тенденцію до збільшення рівня сироваткового $\beta_{2}$-мікроглобуліну $\left(\beta_{2}-\mathrm{MГ}\right)$ та значні відмінності основних показників гематологічного та імунологічного профрілю порівняно з групою пацієнтів без захворювань нервової системи.

Мета дослідження - визначити рівень $\beta_{2}$-мікроглобуліну та його зв'язок з основними гематологічними та імунологічними показниками у пацієнтів 4 клінічної стадії ВІЛ-інфрекції при наявності та відсутності захворювань центральної нервової системи.

Матеріали і методи. У дослідження включено 77 пацієнтів із 4 клінічною стадією ВІЛ-інфекції віком від 20 до 56 років, яких поділили на дві групи: першу групу склали 38 пацієнтів із характерними для відповідної клінічної стадії захворюваннями, окрім неврологічних, другу - 39 пацієнтів, які мали ВІЛ-асоційовані неврологічні захворювання. Групу контролю становили 15 здорових донорів відповідної статі та віку. Визначення $\beta_{2}$-мікроглобуліну проводилось за методом ІФА зі стандартними тестсистемами (вир. США). Статистичну обробку результатів проводили за допомогою ліцензійного програмного продукту
\end{abstract} STATISTICA v.6.1®.

Результати досліджень та їх обговорення. Встановлено значну відмінність між маркерами імунного статусу та показниками гемограми. Серед тих, хто мав неврологічні захворювання (друга група), визначалась лейкопенія на рівні $(3,88 \pm 0,27)$ Г/л проти $(5,07 \pm 0,27)$ Г/л $(p<0,01)$, середня кількість тромбоцитів була нижче в 1,2 раза $(p<0,05)$, а показник ШОЕ - більшим у 2,7 раза ( $<<0,001)$, ніж у пацієнтів 4 клінічної стадії ВІЛ без неврологічних захворювань (перша група). Відносна та абсолютна кількість Т-лімфоцитів хелперів (ТЛ) у пацієнтів другої групи була у 1,9 і 3 раза меншою за відповідні показники у хворих першої групи ( $<0,001)$. Суттєві відмінності мала загальна кількість лімфоцитів $(p<0,001)$ і Т-лімфоцитів $(\mathrm{p}<0,01)$. Середній показник вірусного навантаження (BH) РНК ВІЛ у хворих другої групи (Log10 BH - 5,02 коп/мл) перевищував показник першої групи більше, ніж на порядок - 3,90 коп/мл $(p<0,01)$. Дослідження маркера імунної активації $\beta_{2}$-МГ виявило стійку тенденцію до збільшення рівня цього білка у пацієнтів із ВІЛ-інфекцією при наявності неврологічних захворювань ( $<0,05$ порівняно 3 групою пацієнтів без неврологічних захворювань). За результатами кореляційного аналізу, в пацієнтів із 4 клінічною стадією ВІЛ-інфекції, незалежно від наявності неврологічних захворювань, виявлено достовірні зв'язки між рівнем $\beta_{2}-\mathrm{MГ}$ та ВН і імунологічними та гематологічними показниками. Так, рівень цього білка прямо корелював 3 ШОЕ ( $r s=0,42 ; p<0,001)$ та показником BН PHК ВІЛ ( $r s=0,23 ; p<0,05)$. Зростання рівня $\beta_{2}$-МГ було пов'язане зі зниженням абсолютної кількості ТЛ ( $r s=-0,40 ; p<0,001)$ і ТЛX (rs=-0,39; $p<0,001)$, загального числа лімфроцитів (rs=-0,43; p $<0,001)$ і відносної кількості ТЛХ у сироватці крові $(r s=-0,36 ; p<0,01)$. Більш виразними були кореляції у пацієнтів із ВІЛасоційованими неврологічними захворюваннями.

Висновки. Пацієнти з ВІЛ-асоційованими неврологічними захворюваннями, мають суттєві відмінності всіх основних показників гематологічного та імунологічного профрілю порівняно з групою пацієнтів без захворювань нервової системи. Тенденція до збільшення рівня сироваткового $\beta_{2}$-МГ при наявності неврологічних захворювань паралельно зі значними змінами імунологічних та гематологічних показників може бути використана для прогностичної моделі розвитку ВІЛ-асоційованих неврологічних захворювань.

Ключові слова: ВІЛ-інфекція; ВІЛ-асоційовані неврологічні захворювання; $\beta_{2}$-мікроглобулін; гематологічний; імунологічний профріль.

ВСтуп Неврологічні захворювання, що розвиваються у пацієнтів із ВІЛ-інфрекцією, становлять на сьогодні велику проблему за рахунок значної захворюваності та смертності [1]. Це викликає потребу більш детального вивчення імунопатогенезу та пошуку ефективних діагностичних критеріїв розвитку означеної патології. Відомо, що при запаленні, яке призводить до дисоціації та деградації тканин, відбувається визволення $\beta_{2}$ мікроглобуліну ( $\left.\beta_{2}-\mathrm{MГ}\right)$ у всі біологічні рідини. Цей білок $€$ компонентом комплексу гістосумісності класу 1 у якості циркулюючого фактора. Доведено роль $\beta_{2}-\mathrm{MГ,} \mathrm{як}$ важливого маркера імунної активації при визначенні активності ВІЛ-інорекції: підвищення цього білка пов'язують із прогресуванням ВІЛ, та ризиком смерті [2-9]. Крім того, відомо, що підвищення рівня $\beta_{2}-\mathrm{MГ} \mathrm{в}$ спинномозковій рідині (СМР) корелює з прогресуванням захворювань нервової системи, а зниження з успішним результатом терапії [6].

Доведено, що клітинна ланка імунної системи в ЦНС може бути активованою на ранніх стадіях ВІЛ, а патологічні зміни рівня $\beta_{2}-\mathrm{MГ} \mathrm{у} \mathrm{ЦНС} \mathrm{мають} \mathrm{паралельний} \mathrm{розви-}$ ток зі змінами означеного показника крові [10]. Рівні ВМГ у СМР та крові пов'язані зі стадіями ВІЛ [11]. Більш високі концентрації $\beta_{2}$-МГ у ЦНС виявлені в пацієнтів із розвинутою деменцією [10]. Разом з тим, на практиці в багатьох випадках проблематичним стає дослідження СМР із-за неможливості проведення, за різних причин, у необхідний час люмбальної пункції. Це викликає необхідність вивчення маркерів сироватки крові як більш доступного дослідження. За даними літератури, про прогресування ВІЛ-інфекції також можуть свідчити зміни показників перифрерійної крові, зокрема анемія, лейкопенія та тромбоцитопенія [12-14]. Можливо, що комплексне визначення вмісту $\beta_{2}$-МГ у сироватці крові разом з імунологічними та основними гематологічними може мати більшу діагностичну ефективність при розвитку неврологічних захворювань у ВІЛ-інфрікованих пацієнтів.

Метою дослідження було визначити рівень $\beta_{2}$ мікроглобуліну та його зв'язок із основними гематологічними та імунологічними показниками у пацієнтів 4 клінічної стадії ВІЛ-інфекції при наявності та відсутності порушень центральної нервової системи (ЦНС).

МАТЕРІАЛИ I МЕТОДИ У дослідження включено 77 пацієнтів із 4 клінічною стадією ВІЛ-інфекції віком від 20 
до 56 років, яких поділили на дві групи: першу групу склали 38 пацієнтів із характерними для відповідної клінічної стадії захворюваннями, окрім неврологічних, а другу групу - 39 хворих, які мали ВІЛ-асоційовані неврологічні захворювання (туберкульоз, грибкові інсрекції, токсоплазмоз, ЕБВ-енцефаліт, ПМЛ, ВІЛ-асоційовану енцефалопатію). Контрольну групу склали 15 донорів відповідної статі та віку.

Визначення бета-2-мікроглобуліну $\left(\beta_{2}-\mathrm{MГ}\right)$ проводили за методом ІФА зі стандартними тест-системами (вир. США). Статистичну обробку результатів проводили за допомогою ліцензійного програмного продукту STATISTICA v.6.1®. 3 урахуванням типу розподілу кількісних даних (критерій Колмогорова-Смирнова 3 поправкою Ліллієсорса) використовували параметричні або непараметричні характеристики і методи порівняння: у випадку нормального розподілу - середню арифметичну (M) та її стандартну похибку (m), критерій Стьюдента (t); при ненормальному розподілі - медіану (Me), інтерквартильний розмах (LQ-HQ), критерій Манна-Уїтні (U). Порівняння з контрольною групою проводили за критерієм Даннетта. Виконували кореляційний аналіз із розрахунком коефріцієнтів рангової кореляції Спірмена $\left(r_{s}\right)$. Критичне значення рівня значимості $(p)$ приймали $<5 \%(p<0,05)$.

РЕЗУЛЬТАТИ ДОСЛІДЖЕНЬ ТА ЇХ ОБГОВОРЕННЯ Порівняльний аналіз даних пацієнтів із 4 клінічною стадією ВІЛ-інфрекції та наявністю або відсутністю ВІЛасоційованих неврологічних захворювань довів суттєві відмінності всіх досліджуваних лабораторних показників (табл. 1).

Так, серед тих, хто мав неврологічні захворювання, переважала лейкопенія (середній показник $(3,88 \pm 0,27)$ г/л проти $(5,07 \pm 0,27)$ г/л; р<0,01), середня кількість тромбоцитів була зниженою в 1,2 раза $(p<0,05)$, а показник шОЕ - збільшеним в 2,7 раза $(p<0,001)$, ніж у пацієнтів 4 клінічної стадії ВІЛ без неврологічних захворювань. Відносна та абсолютна кількість ТЛХ у пацієнтів другої групи була у 1,9 і 3 рази меншою за відповідні показники у пацієнтів першої групи $(p<0,001)$. Суттєві відмінності між групами також відзначено відносно показників загальної кількості лімфоцитів $(p<0,001)$ і ТЛ $(p<0,01)$. Середній показник вірусного навантаження РНК у хворих із 4 клінічною стадією ВІЛ і неврологічними порушеннями ЦНС $\left(\log _{10} \mathrm{BH}-5,02\right.$ коп/мл) перевищував показники в групі без таких порушень більше, ніж на порядок - 3,90 коп/мл $(p<0,01)$.

Дослідження маркера імунної активації $\beta_{2}-$ МГ виявило стійку тенденцію до збільшення рівнів цього білка у пацієнтів із ВІЛ-інфекцією, порівняно зі здоровими особами (у 9-10 рази; $p<0,001$ ), та за наявності неврологічних захворювань ЦНС ( $<<0,05$ порівняно $з$ першою групою) (табл. 2).

За результатами кореляційного аналізу в пацієнтів із 4 клінічною стадією ВІЛ-інфекції, незалежно від наявності неврологічних захворювань, виявлено достовірні зв'язки між рівнем $\beta_{2}$-МГ та імунологічними і гематологічними показниками. Так, рівень цього білка прямо корелював із ШОЕ $\left(r_{s}=0,42 ; p<0,001\right)$ та показником ВН РНК ВІЛ $\left(r_{s}=0,23 ; p<0,05\right)$. Зростання рівня $\beta_{2}-$ МГ було пов'язане зі зниженням абсолютної кількості ТЛ ( $r_{s}=-0,40$; $p<0,001)$ і ТЛX $\left(r_{s}=-0,39 ; p<0,001\right)$, загального числа лімфоцитів $\left(r_{s}=-0,43 ; p<0,001\right)$ і відносної кількості ТЛХ у сироватці крові $\left(r_{s}=-0,36 ; p<0,01\right)$. Причому виявлені кореляції були виразнішими у пацієнтів із ВІЛ-асоційованими захворюваннями ЦНС (табл. 3).

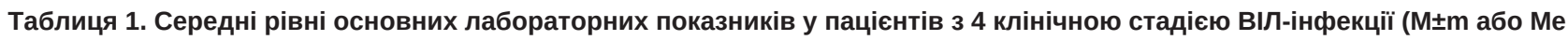
(LQ-HQ))

\begin{tabular}{|l|c|c|c|}
\hline \multicolumn{1}{|c|}{ Показник } & Перша група $(\mathrm{n}=38)$ & Друга група $(\mathrm{n}=39)$ & Відмінності між групами (p) \\
\hline Гемоглобін (г/л) & $127,0 \pm 3,4$ & $117,6 \pm 3,0$ & 0,039 \\
\hline Лейкоцити (г/л) & $5,07 \pm 0,27$ & $3,88 \pm 0,27$ & 0,002 \\
\hline Тромбоцити (г/л) & $204,7 \pm 9,5$ & $175,1 \pm 11,6$ & $<050$ \\
\hline ШОЕ (мм/год) & $12(6-25)$ & $32(20-50)$ & $0,001^{*}$ \\
\hline CD3+ТЛ (ТЛ) (\%) & $76(69-83)$ & $48(16-76)$ & $0,002^{*}$ \\
\hline CD3+ТЛ (кл/мкл) & $899(642-1189)$ & $454(218-749)$ & $<0,001^{*}$ \\
\hline CD3+CD4+ ТЛ (ТЛХ) (\%) & $13,5(8-19)$ & $7(3-12)$ & $<0,001^{*}$ \\
\hline CD3+СD4+ТЛ (кл/мкл) & $157,5(102-217)$ & $53(24-79)$ & $<0,001^{*}$ \\
\hline Лімфоцити (кл/мкл) & $1223,5(989-1543)$ & $632(382-1152)$ & $0,004^{*}$ \\
\hline ВІЛ РНК (ВН) (коп/мл) & $8190,5(40-158207)$ & $105395(14313-728432)$ & $0,004^{*}$ \\
\hline Lоg10 ВН (коп/мл) & $3,90(1,6-5,2)$ & $5,02(4,16-5,86)$ & \\
\hline
\end{tabular}

Примітка. p - рівень значимості відмінностей середніх показників у відповідних групах за критеріями Стьюдента або Манна-Уїтні (*).

Таблиця 2. Результати дослідження рівня бета-2-мікроглобуліну в сироватці крові пацієнтів 34 клінічною стадією ВІЛ-інфекції

\begin{tabular}{|l|c|c|c|}
\hline \multirow{2}{*}{\multicolumn{1}{|c|}{ Статистичний показник }} & Донори & \multicolumn{2}{c|}{ ВІЛ-іноріковані } \\
\cline { 2 - 4 } & контрольна група $(\mathrm{n}=15)$ & перша група $(\mathrm{n}=38)$ & друга група $(\mathrm{n}=39)$ \\
\hline Мінімум - максимум (нг/мл) & $0,1-1,2$ & 9,5 & $3-13$ \\
\hline Me (LQ - HQ) (нг/мл) & $1,0(0,8-1,1)$ & $10,1(9-11)$ \\
\hline Відмінності між групами & $\mathrm{p}<0,001$ з першою і другою групами & $\mathrm{p}_{1-2}=0,015$ \\
\hline
\end{tabular}

Примітки: 1) р - рівень значимості відмінностей середніх показників порівняно з контролем за критерієм Даннетта;

2) $\mathrm{p}_{1-2}-$ між першою і другою групами за критерієм Манна-Уїтні. 
Таблиця 3. Коефіцієнти кореляції Спирмена $\left(r_{s}\right)$ між рівнем $\beta_{2}-\mathrm{MГ}$ та імунологічними і гематологічними показниками у пацієнтів із 4 клінічною стадією ВІЛ-інфекції

\begin{tabular}{|c|c|c|c|}
\hline Показник & Перша група (n=38) & Друга група (n=39) & У цілому $(\mathrm{n}=77)$ \\
\hline ШОЕ (мм/год) & 0,29 & $0,33^{\star}$ & $0,42^{\star \star \star}$ \\
\hline CD3+ТЛ (кл/мкл) & $-0,17$ & $-0,56^{\star \star \star}$ & $-0,40^{\star \star \star}$ \\
\hline CD3+CD4+ ТЛ (ТЛХ) (\%) & $-0,13$ & $-0,32^{*}$ & $-0,36^{\star *}$ \\
\hline CD3+CD4+TЛ (кл/мкл) & $-0,16$ & $-0,27$ & $-0,39^{\star * \star}$ \\
\hline Лімфоцити (кл/мкл) & $-0,25$ & $-0,52^{\star \star \star}$ & $-0,43^{\star \star \star}$ \\
\hline ВІЛ РНК (ВН) (коп/мл) & 0,18 & 0,12 & $0,23^{*}$ \\
\hline
\end{tabular}

Примітки: 1) * - рівень значимості коефіцієнта кореляції, $p<0,05$;

2) $* *-p<0,01$;

3) $* * *-p<0,001$

ВИсновкИ У всіх пацієнтів із 4 клінічною стадією ВІЛ-інфекції при зростанні рівня імуносупресії та збільшенні кількості РНК ВІЛ у крові підвищується рівень $\beta_{2}-\mathrm{MГ}$, що може бути використаний в якості предиктора прогресування ВІЛ-інфрекції. Тенденція до збільшення рівня

сироваткового $\beta_{2}$-МГ при розвитку неврологічних захворювань ЦНС паралельно зі значними змінами імунологічних та гематологічних показників, при більшій кількості спостережень може бути використана для прогностичної моделі розвитку ВІЛ-асоційованих уражень ЦНС.

\section{СПИСОК ЛІТЕРАТУРИ}

1. Bilgrami M. Neurologic diseases in HIV-infected patients / M. Bilgrami, P. O'Keefe // Clin. Neurol. - 2014. - Vol. 121 P. 1321-1344.

2. Halota W. Serum neopterin and beta2-microglobulin concentration as" prognostic markers" of AIDS / W. Halota, B. Jaruga, M. Pawiowska // Polski merkuriusz lekarski: organ Polskiego Towarzystwa Lekarskiego. - 2002. - Vol. 13, No. 74. - P. 126-128.

3. Mocroft A. The relationship between beta-2-microglobulin, CD4 lymphocyte count, AIDS and death in HIV-positive individuals / A. Mocroft // Epidemiology and Infection. - 1997. - Vol. 118, No. 3. - P. 259-266.

4. Gupta S. M., Ray K., Bala M. Evaluation of beta2 microglobulin level as a marker to determine HIVIAIDS progression / S. M. Gupta, K. Ray, M. Bala // The Journal of Communicable Diseases. - 2004. - Vol. 36, No. 3. - P. 166-170.

5. Wanchu A. Beta2 microglobulin as a surrogate marker for HIV infection: good correlation with CD4 counts / A. Wanchu // Indian Journal of Pathology \& Microbiology. -2004. - Vol. 47, No. 2. - P. 298-301.

6. Svatoтov J. Beta2-microglobulin as a diagnostic marker in cerebrospinal fluid: a follow-up study / J. Svatotov // Disease Markers. - 2014. - Vol. 2014.

7. Прогностическое значение $\beta_{2}$-микроглобулина и неоптерина на разних клинических стадиях ВИЧ-инфекции / О. А. Воликова, Л. Р. Шостакович-Корецка, Е. Ю. Литвин, Е. А. Кушнерова // Медичний фрорум. - 2014. - № 2. - С. 49-54.

8. Використання $\beta_{2}$-мікроглобуліну та неоптерину для прогнозування перебігу ВІЛ-інфекції / О. О. Волікова, Л. Р. Шоста-
кович-Корецька, К. Ю. Литвин [та ін.] // Актуальні інфекційні захворювання. Клініка, діагностика, лікування та профрілактика : зб. наук. праць Укр. військово-медичної академії. - К., 2015. № 40. - С. 381-387.

9. Прогностичне значення $\beta_{2}$-мікроглобуліну у ВІЛ-інфікованих пацієнтів / О. О. Волікова, Л. Р. Шостакович-Корецька, К. Ю. Литвин [та ін.] : матеріали наук.-практ. конфр. “Фармакотерапія при інфекційних захворюваннях". - К., 6-7 квітня, 2017. C. 25-26.

10. Sunnerborg A. B. Elevated neopterin and beta2-microglobulin levels in blood and cerebrospinal fluid occur early in HIV-1 infection / A. B. Sunnerborg // Aids. - 1989. - Vol. 3, No. 5. - P. 277-284.

11. Price R. W. Evolving character of chronic central nervous system HIV infection / R. W. Price // Seminars in neurology. - Thieme Medical Publishers. - 2014. - Vol. 34, No. 01. - P. 007-013.

12. Sullivan P. S. Surveillance for thrombocytopenia in persons infected with HIV: results from the multistate adult and adolescent spectrum of disease project / P. S. Sullivan // JAIDS Journal of Acquired Immune Deficiency Syndromes. - 1997. - Vol. 8, No. 4. - P. 374-379.

13. Attili S. V. S. Hematological profile of HIV patients in relation to immune status-a hospital-based cohort from Varanasi, North India I S. V. S. Attili // Turk J. Hematol. - 2008. - Vol. 25, No. 1. P. 13-19.

14. Dikshit B. Profile of hematological abnormalities of Indian HIV infected individuals / B. Dikshit // BMC Hematology. - 2009. Vol. 9, No. 1. - P. 5.

\section{ANALYSIS OF CHANGES OF SERUM BETA-2-MICROGLOBULIN AND HEMATOLOGICAL PARAMETERS IN PATIENTS WITH HIV-ASSOCIATED NEUROLOGICAL DISEASES}

Summary. Patients with the fourth clinical stage of HIV infection with neurological involvement present with tendency to increase the level of serum beta-2-microglobulin (MG) and to show significant differences in the main indicators of the hematological and immunological profile in comparison with the group of patients without involvement of the nervous system.

The aim of the study - to determine the level of 2-microglobulin and its relation to the main hematological and immunological parameters in patients of the fourth clinical stage of HIV infection in the presence or absence of diseases of the central nervous system. 
Materials and Methods. The study included 77 patients with the fourth clinical stage of HIV infection at the age of 20 to 56 years, divided into two groups: the first group consisted of 38 patients with clinical-relevant diseases other than neurological, the second group consisted of 39 patients who had HIV-associated neurological diseases. The control group consisted of 15 healthy donors, of corresponding sex and age distribution. Determination of beta-2-microglobulin was performed by ELISA with standard test systems (US Ave). The statistical processing of the results was carried out using the licensed software product STATISTICA v.6.1®.

Results and Discussion. A significant difference has been established for both markers of the immune status and hemogram indices. Among those who had neurological diseases (group 2), leucopenia was determined at $3.88 \pm 0.27 \mathrm{~g} / \mathrm{L}$ versus $5.07 \pm 0.27 \mathrm{~g} / \mathrm{L}(p<0.01$ ), the mean number of platelets was 1.2 times lower $(p<0.05)$, and the ESR index is more than 2.7 times higher $(p<0.001)$ than in patients of the fourth clinical stage of HIV without neurological diseases (group 1). Relative and absolute number of T-lymphocytes of helpers $(T L)$ in patients of the group 2 was 1.9 and 3 times less than corresponding parameters in patients of the group $1(p<0.001)$. Significant differences were shown in the number of lymphocytes $(p<0.001)$ and T-lymphocytes $(p<0.01)$. The mean viral load $(V L)$ of HIV RNA in patients of the group 2 ( $\log 10 \mathrm{VL}-5.02$ copies $/ \mathrm{ml}$ ) exceeded the index of the group 1 by more than an order of magnitude -3.90 copeis/ $\mathrm{ml}(p<0.01)$. The study of the marker of immune activation of B2-MG revealed a steady tendency to increase the level of this protein in patients with HIV infection in the presence of neurological diseases $(p<0.05$ compared to the group of patients without neurological diseases). Based on the results of the correlation analysis in patients with the fourth clinical stage of HIV infection, regardless of the presence of neurological diseases, reliable connections between the level of B2-MG and VL and immunological and hematological parameters were found. Thus, the level of this protein directly correlated with ESR ( $r s=0.42, p<0.001$ ) and the indicator of VL RNA of HIV ( $r s=0.23, p<0.05)$. The increase in the level of $\beta_{2}-\mathrm{MG}$ was associated with a decrease in the absolute number of $T L(r s=-0.40, p$ $<0.001)$ and TLH ( $r s=-0.39, p<0.001)$, the total number of lymphocytes ( $r s=-0.43 ; p<0.001)$ and the relative amount of TLC in the blood serum ( $r s=-0.36, p<0.01$ ). More expressive were correlations in patients with HIV associated neurological diseases.

Conclusions. Patients with HIV-associated neurological diseases have significant differences in all major indicators of the hematological and immunological profile compared with the group of patients without diseases of the nervous system. The tendency to increase the level of serum $\beta_{2}-M G$ in the presence of neurological diseases in parallel with significant changes in immunological and hematological parameters can be used for the prognostic model of the development of HIV-associated neurological diseases.

Key words: HIV infection; HIV-associated neurological diseases; 2-microglobulin; hematological; immunological profile.

СЛ. Р. Шостакович-Корецкая, Е. Ю. Литвин, И. А. Губарь, О. А. Воликова, З. А. Чикаренко, Е. А. Кушнерова, Е. В. Шевелева ГУ “Днепропетровская медицинская академия МЗ Украины”

\section{АНАЛИЗ ИЗМЕНЕНИЙ СЫВОРОТОЧНОГО БЕТА-2-МИКРОГЛОБУЛИНА И ПОКАЗАТЕЛЕЙ ГЕМАТОЛОГИЧЕСКОГО ПРОФИЛЯ У ПАЦИЕНТОВ С ВИЧ-АССОЦИИРОВАННЫМИ НЕВРОЛОГИЧЕСКИМИ ЗАБОЛЕВАНИЯМИ}

Резюме. Пациенты 4 клинической стадии ВИЧ-инфекции с неврологическими заболеваниями имеют тенденцию к увеличению уровня сывороточного бета-2-микроглобулина $\left(\beta_{2}-\mathrm{MГ}\right)$ и значительные отличия основных показателей гематологического и иммунологического профиля по сравнению с группой пациентов без заболеваний нервной системы.

Цель исследования - определить уровень $\beta_{2}$-микроглобулина и его связь с основными гематологическими и иммунологическими показателями у пациентов 4 клинической стадии ВИЧ-инфекции при наличии и отсутствии заболеваний центральной нервной системы.

Материалы и методы. В исследование включено 77 пациентов с 4 клинической стадией ВИЧ-иноекции в возрасте от 20 до 56 лет, разделенные на две группы: первую группу составили 38 пациентов с характерными для соответствующей клинической стадии заболеваниями, кроме неврологических, вторую группу - 39 пациентов, которые имели ВИЧ-ассоциированные неврологические заболевания. Группу контроля составили 15 здоровых доноров, соответствующего пола и возраста. Определение $\beta_{2}$-микроглобулина проводилось методом ИФА со стандартными тест-системами (пр. США). Статистическую обработку результатов проводили с помощью лицензионного программного продукта STATISTICA v.6.1®.

Результаты исследований и их обсуждение. Установлено значительное отличие как маркеров иммунного статуса, так и показателей гемограммы. Среди тех, кто имел неврологические заболевания (вторая группа), определялась лейкопения на уровне $(3,88 \pm 0,27)$ г/л против $(5,07 \pm 0,27)$ г/л $(p<0,01)$, среднее количество тромбоцитов было ниже в 1,2 раза ( $<0,05)$, а показатель СОЭ - более чем в 2,7 раза $(p<0,001)$ выше, чем у пациентов 4 клинической стадии Вич без неврологических заболеваний (первая группа). Относительное и абсолютное количество Т-лимсоцитов хелперов (ТЛ) у пациентов второй группы было в 1,9 и 3 раза меньше соответствующих показателей у пациентов первой группы ( $<0,001)$. Существенные различия имело количество лимфоцитов $(\mathrm{p}<0,001)$ и Т-лимфоцитов ( $<<0,01)$. Средний показатель вирусной нагрузки (BH) РНК ВИЧ у больных второй группы (Log10 BH - 5,02 коп/мл) превышал показатель первой группы более чем на порядок - 3,90 коп/мл (p<0,01). Исследование маркера иммунной активации $\beta_{2}-\mathrm{MГ} \mathrm{выявило} \mathrm{устойчивую} \mathrm{тенденцию} \mathrm{к} \mathrm{увеличению} \mathrm{уровня} \mathrm{этого} \mathrm{белка} \mathrm{у} \mathrm{пациентов} \mathrm{с} \mathrm{ВИЧ-инсекцией} \mathrm{при}$ наличии неврологических заболеваний ( $<<0,05$ по сравнению с группой пациентов без неврологических заболеваний). По результатам корреляционного анализа у пациентов с 4 клинической стадией ВИЧ-инсеекции, независимо от наличия неврологических заболеваний, обнаружены достоверные связи между уровнем $\beta_{2}-\mathrm{MГ} \mathrm{и} \mathrm{ВН} \mathrm{и} \mathrm{иммунологическими} \mathrm{и} \mathrm{гематологическими} \mathrm{показате-}$ лями. Так, уровень этого белка прямо коррелировал с СОЭ (rs=0,42; $<<0,001)$ и показателем ВН РНК ВИЧ (rs=0,23; p<0,05). Рост уровня $\beta_{2}-$ МГ был связан со снижением абсолютного количества ТЛ (rs=-0,40; $\left.p<0,001\right)$ и ТлX $(r s=-0,39 ; p<0,001)$, общего числа лимсоцитов (rs=-0,43; p<0,001) и относительного количества ТЛХ в сыворотке крови (rs=-0,36; p<0,01). Более выразительными были корреляции у пациентов с ВИЧ-ассоциированными неврологическими заболеваниями.

Выводы. Пациенты с ВИЧ-ассоциированными неврологическими заболеваниями имеют существенные различия всех основных показателей гематологического и иммунологического профиля по сравнению с группой пациентов без заболеваний нервной системы. Тенденция к увеличению уровня сывороточного $\beta_{2}$-МГ при наличии неврологических заболеваний параллельно со значительными изменениями иммунологических и гематологических показателей может быть использована для прогностической модели развития ВИЧ-ассоциированных неврологических заболеваний.

Ключевые слова: ВИЧ-инфекция; ВИЧ-ассоциированные неврологические заболевания; $\beta_{2}$-микроглобулин; гематологический; иммунологический профиль. 